CHAPTER 212

\title{
THE BEACH REHABILITATION PROJECT AT OSTEND-BELGIUM
}

\author{
ir. R. SIMOEN* \\ ir. H. VERSLYPE** \\ ir. D. VANDENBOSSCHE***
}

\begin{abstract}
Steady erosion has occured on the beaches at ostend, Belgium, especially on the section between the Casino and the Harbour Entrance. The gravel beach supported by a sandfill core has been proven to be a feasible and cost effective flood protection alternative, the first objective of the long term beach enhancement programme. Secondary goals are also met such as : new beach recreational facilities in safe conditions for the public; the economic incentive for the needed redevelopment of this part of down-town ostend and the beach front ; the conservation of the present sea-view from the promenade.
\end{abstract}

\section{Introduction}

Since the end of the 19th century the beaches at ostend, Belgium have been popular holiday resorts. However, steady erosion has occured, especially on the beach section between the Casino-Kursaal and the Harbour entrance (see fig. 1). Indeed, the beach front promenade was constructed along the line of the 17 th century fortifications of the city, which protrude into the sea beyond the natural coastline over ca. $150 \mathrm{~m}$. A system of huge perpendicular groynes, ca. $200 \mathrm{~m}$ long could only slow down the erosion process.

\footnotetext{
* Inspector General, Ministry of Pullic Works, Coastal Service, Administratief Centrum, Vrijhavenstraat 3, B-8400 Oostende, Belgium

** Chief Engineer - Director, Ministry of Public Works, Coastal Service, Administratief Centrum, Vrijhavenstraat $3, \mathrm{~B}-8400$ oostende.

*** Technical Director, HAECON (Harbour and Engineering Consultants) N.V., Deinsesteenweg 110, B-9810 Gent.
} 


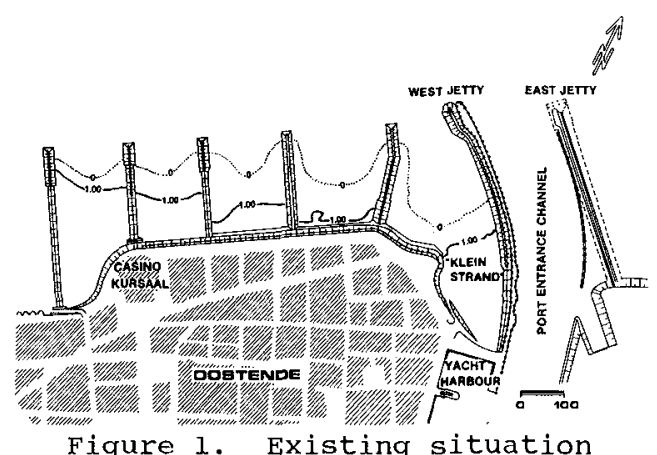

At that time, the coastal protection consisted of :

- a seawall up to $z+9.80$ at the promenade level, with a slope revetment of natural stone masonry on $10 / 4$ slope ;

- a sandy beach with a gentle slope of $1: 60$, the level at the seawall toe is around $z+2.80$ to $3.00 \mathrm{~m}$, almost the Mean sea Level (MSL). As the beach had reached this rather low level, the main functions of the coastal defence, as depicted on cross-section (fig. 2) became progressively inadequate e.g. :

* flood protection : during storm surges ostend's lower downtown became more frequently flooded by waves overtopping the seawall. During extreme storm surges as in February 1953, the seawall was even partially destroyed.

* recreation : remained only viable on the "Klein strand" beach section ( $f i g .1)$. The remainder being flooded at mean sea level up to high water. Practical use of the beach is limited to only a brief period at low-water. Compared with other similar beach fronts at ostend and elsewhere along the Belgian coast the real estate properties are consequently less developed to modern age standards.

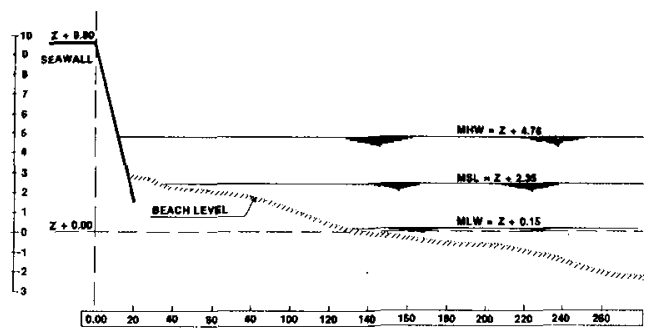

Figure 2. Typical cross-section existing beach

A flood protection enhancement programme, realized after the dramatic storm surge of February 1953 and extended after the winter storms of January 1976, resulted in a small storm surge barrier wall on top of the seawall up to level 
$\mathrm{Z}+10.20$ and associated storm surge sewer system. This programme gives results but only in the short term.

\section{The beach rehabilitation project}

The National Ministry of Public Works, Coastal Service entrusted HAECON, Consulting Engineers of Ghent, to elaborate a beach enhancement programme in order to provide in the long term :

- flood protection by preventing storm surge waves overtopping the seawall ;

- additionally the realization of a recreational beach potential by both a dry sun beach, and to a lesser extent a bathing beach.

\section{Physical design data}

3.1. Beach and shore morphology has been analyzed from beach profiles and bathymetry soundings from 171 up to 182 .

The beach in the project area although at a low level is compared to other sections stabilized on a typical average slope of 1:60. The beach foot is situated at the $2-5.00$ contour. From this to the LW-line the depth contours are almost parallel to the coast. Off-shore to deep water the wave attenuation is influenced by the system of banks (ca. $z-6.00)$ and channels $(z-8.00$ to $z-10.00)$ of the Flemish Bank area.

\subsection{Hydrographic data}

A comprehensive set of data was available concerning : tides, currents, surges and waves.

3.2.1. Tides : the high and low water characteristics at spring tide are : MHWS $=2+4.75 ;$ MLWS $=z+0.15$. The period of the semi-diurnal tide is : $12 \mathrm{~h} 17 \mathrm{~min}$.

3.2.2. Surges : the exceedance frequency of high waters were established by linear regression of the tide observations of the Ministry of Public Works' Hydrographic Service from 1952 to 1967 (see fig. 4). From this the decennial surge level has been estimated at $z+6.00 \mathrm{~m}$; the centennial level at $6.40 \mathrm{~m}$.

3.2.3. Waves : from deepwater wave data, measured from 1977 to 1980 at the lightship Westhinder. The near-shore exceedance frequency of significant waves was established with mathematical refraction analysis. The annual significant wave height is estimated at $\mathrm{Hs}=4.00 \mathrm{~m}$; the centennial significant wave height $4.80 \mathrm{~m}$ is depth limited. From this data the frequency of occurrence of wave periods was also established. The peak period of the wave energy spectrum is around 6 to $6.5 \mathrm{sec}$. 


\subsection{Beach and beach fill materials}

The existing beach sand is a rather fine material, on average characterized by $: D_{50}=173 \mu$ and $D_{90}=688 \mu$.

The typical grain size distribution of the beach fill sand from the Kwintebank and the gravel to be found off Dieppe, Wisant and Wight, Thames, is given on fig. 3. One should note that the sand quantity in the gravel load can reach $30 \%$ by weight.

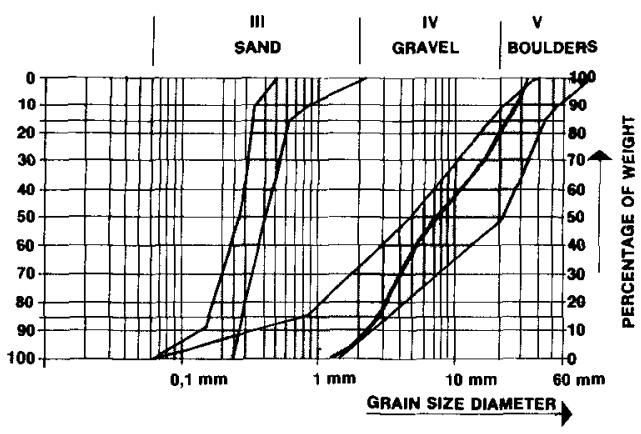

Figure 3. Grain size distribution tolerances of beach fill sand and gravel

\section{Planning and design}

4.1. For the beach rehabilitation, a straight sand fill solution was technically unfeasible because of the adjoining access-channel to the Port of Ostend. Indeed, in order to prevent higher sedimentation in this channel, the beach replenishment should be limited within the confines of the existing groyne system and the western harbour jetty.

4.2. The main conceptual design alternatives were assessed :

- Figure 4 - the spending beach concept : consisting of a beachfill from $\mathrm{HW}-$ level $(\mathrm{Z}+4.75)$ at the seawall down to LW-level whereas the beach foot is supported by a low crested rubble mound at level $\mathrm{Z}+0,75$ parallel to the coast. The slope of the replenished beach is designed at $1: 50$.

- Figure 5: the concept of a gravel beach supported by a $50 \mathrm{~m}$ wide sandfill core with the gravel beach crest at $\mathrm{Z}+6.00$, the sand level at the seawall up to $\mathrm{Z}+7.00$. Based on literature data the gravel slope has been designed at $1: 7$ and the required gravel layer thickness estimated around $3.00 \mathrm{~m}$, for gravel with size distribution $D_{50}=12 \mathrm{~mm} / \mathrm{D}_{90}=30 \mathrm{~mm}, \mathrm{HO}_{0}=4.00 \mathrm{~m}$ and $\mathrm{T}=6 \mathrm{sec}$. 


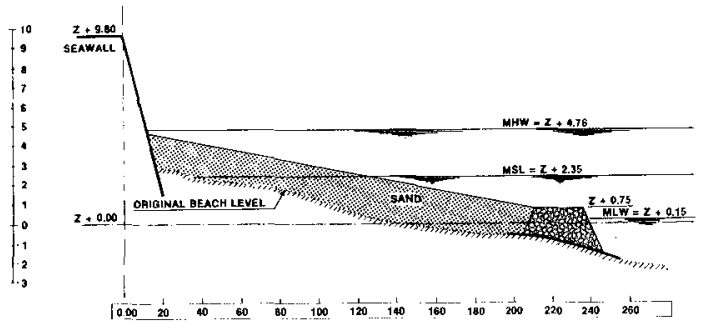

Figure 4. The spending beach concept

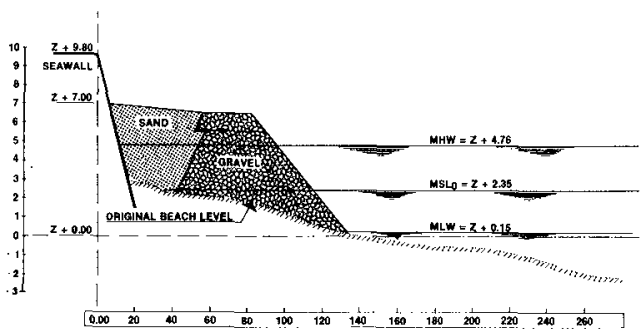

Figure 5. The gravel beach concept

Both the designs, together with the existing beach seawall configuration were evaluated for the occurrences of wave overtopping, transport capacity of beach material, accomplishment of design functions and other related aspects.

4.3. The results of the wave overtopping calculation are given in the table below.

\begin{tabular}{|l|l|}
\hline * Existing situation (fig. 2) \\
* Spending beach \\
$\begin{array}{l}\text { - at designed level (fig. 4) } \\
\text { - at assumed eroded level } \\
\text { (-1.00 m) } \\
\text { overtopping (N/year) }\end{array}$ \\
* Gravel beach (fig. 5)
\end{tabular}

TABLE : Estimated wave overtopping rate.

The results in the existing situation fit well with those experienced on site. 
4.4. The morphological aspects have been assessed mainly by evaluating the longshore transport capacity especially the eastbound component towards the Port Entrance Channel.

4.4.1. Present situation : Longshore transport is to a large extent blocked by the groynes. The eastbound transport capacity for $D_{50}=173 \mu / D_{90}=242 \mu$ can be estimated at $400,000 \mathrm{~m}^{3} /$ year. The resultant longshore transport is up to $180,000 \mathrm{~m}^{3} /$ year eastbound.

4.4.2. Spending beach : The longshore transport capacity for a beach fill of $D_{50}=371 \mu / D_{90}=600 \mu$ has been estimated on $140,000 \mathrm{~m}^{3} / \mathrm{Yr}$ (eastbound component) and 20,000 $\mathrm{m}^{3}$ year (resultant eastbound). The resultant longshore transport may be caught in the "Klein strand" beach section near the West Harbour jetty. Consequently, a higher sedimentation risk in the access-channel is to be excluded.

Despite the decreased transport capacities, compared with the present situation, increased losses due to the higher turbulence caused by wave reflection on the seawall and breaking waves at the rubble mound toe, giving rise to concern about the long-term flood protection efficiency of the concept. Indeed, a lowering of only $1.00 \mathrm{~m}$ brings the wave overtopping almost to the same order of magnitude-zs the present situation ! (see table : from $1.8 \times 10^{-2}$ tides/yr designed to 2 tides/yr, cfr. the present 21 tides/year).

The rubble mound structure prevents the normal exchange of beach material between the replenished upper beach and the foreshore. A prerequisite for a profile in dynamic equilibrium is therefore not met.

As all waves will break on the rubble mound the erosion pits near the structure would create a dangerous situation for the public. Bathing and swimming should not be tolerated.

4.4.3. Gravel beach : The longshore transport capacity will decrease as the beach material is increased by grain size. The resultant is lower than $200 \mathrm{~m}^{3} / \mathrm{yr}$ and the eastbound component less than $8,000 \mathrm{~m}^{3} / \mathrm{yr}$.

The gravel beach and the foreshore represents a natural beach system both in morphology and in grain size distribution. A dynamic equilibrium can be expected with greatly reduced cross-sectional transport losses.

Compared with a sandy beach the gravel beach would not be the preferred choice for a bathing beach, however, by no means create dangerous situations for the public.

\section{Detailed design}

5.1. The retained gravel beach concept (fig. 5) has been designed in detail based on extensive physical scale model 
testing in the wave flume and wave tank facilities of the Ministry of Public Works' Hydraulic Research station at Antwerp.

5.2. The aims of the test programme were:

1) the definition of the equilibrium slope and active layer thickness as a function of the waves ;

2) the study of wave overtopping by defining the water quantities overwashing the seawall;

3 ) the study of some construction phases of the gravel mound in order to establish guidelines for construction.

5.3. The studies on items 1) and 2) were realized on the wave flume in a 2 -dimensional model. The 3-dimensional model has been used for item 3).

The wave flume measures $63.5 \times 4.08 \times 1.45 \mathrm{~m}^{3}$ and is equipped with a Arenfield wave generator and a hydraulic system to simulate the tidal changes of the water levels. Maximal tidal difference can be set up to $1.20 \mathrm{~m}$. The geometric scale of the models was $1 / 12$, time scale $1 / 3.464$.

The model tides schematization was calibrated around a spring tide ( $\mathrm{LW}=\mathrm{Z}-0.10, \mathrm{HW}=\mathrm{Z}+4.00$ and $\mathrm{T}=12 \mathrm{~h} 30$ ).

The irregular model waves correspond to the pierson Moskowitz Spectrum, the theoretical spectrum best fitting with the shallow water wave conditions off the Belgian coast.

The grain size distribution of the model gravel is given on fig. 3 .

5.4. Equilibrium slope and required layer thickness

5.4.1. The results of the tests regarding equilibrium slopes as a function of $\mathrm{Hs}$ and active layer thickness are summarized in fig. 6 .

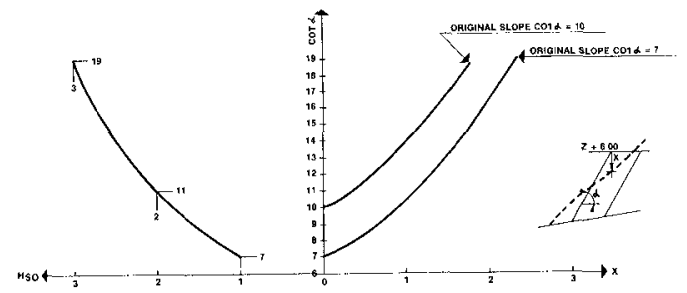

Figure 6. Equilibrium slopes $(\operatorname{cotg} \alpha)$ and active layer thickness $(x)$ in function of significant design wave (Hs)

The behaviour of the gravel beach under a schematic annual wave climate is reported on $\mathrm{fig} .7$. 

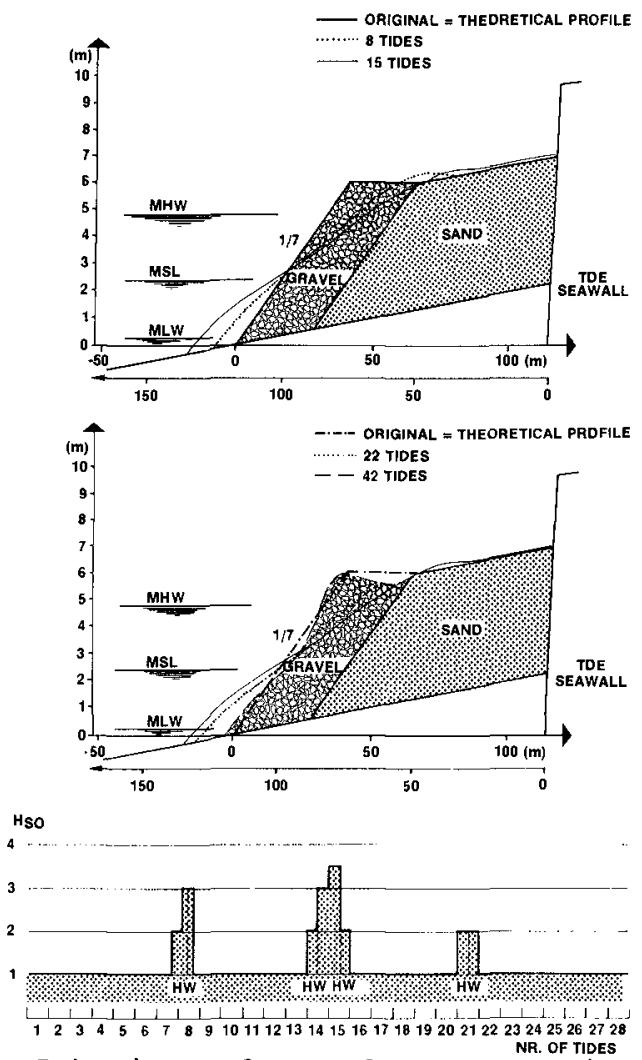

Figure 7. Behaviour of gravel beach profile line under schematic annual wave action

5.4.2. From the test series one determines that :

- the equilibrium slopes range from $1: 7$ over $1: 11$ to $1: 19$ for wave classes $\mathrm{Hso}=1.00,2.00$ and $3.00 \mathrm{~m}$ respectively ;

- the equilibrium slopes are found roughly by a rotation of the slope around MSL.

5.4.3. For the design of the gravel beach following conclusions could be retained :

1) the theoretical design slope should be 1:8, because :

* this slope corresponds with a wave of $\mathrm{Hs}=1.25$ which is exceeded $10 \%$ of the tides ;

* with the slope of 1:7 the gravel beach crest at $Z+6.00$ could be eroded over the whole width of 25.00 $\mathrm{m}$ during one storm with $\mathrm{Hs}=3.00$ to $3.50 \mathrm{~m}$ (ca. 2 times/year) ;

* for the schematic annual wave climat test the final slopes were : $1: 7.50$ to $1: 9$. 
2) the theoretical design crest width may be $25.00 \mathrm{~m}$ with a slope of $1: 8$. Two consecutive tides of $\mathrm{Hs}=3$ to 3.50 $\mathrm{m}$ are needed to erode this width ;

3) the active layer thickness with a slope of $1: 8$ for $\mathrm{H}=$ 3 to $3.50 \mathrm{~m}$ is at equilibrium $2.00 \mathrm{~m}$. A layer thickness of 2.50 to $3.00 \mathrm{~m}$ seems adequate, depending on the safety margin needed.

\subsection{Wave overtopping}

5.5.1. The test series on wave overtopping have been conducted starting from the equilibrium profile resulting from the annual wave climate test serie. With consecutive constant water levels of $\mathrm{z}+4.75 \mathrm{~m} ; \mathrm{z}+5.75, \mathrm{z}+6.25$ and $6.75 \mathrm{~m}$ the water quantities have been measured from irregular overtopping wave fields with $\mathrm{Hs}=3.00, \mathrm{Hs}=3.50$ and $\mathrm{Hs}=4.00 \mathrm{~m}$.

5.5.2. In the existing situation wave overtopping starts when $\mathrm{HW}=4.75 \mathrm{~m}$ (ca. 100 times $/$ year) and $\mathrm{Hs}=2.00 \mathrm{~m}$ (ca. 25 times/year) or 3.4 tides per year. The same quantity of water (ca. $601 / \mathrm{m}^{1} / \mathrm{min}$.) will pass by the gravel beach concept when $\mathrm{HW}=6.25 \mathrm{~m} \Omega_{5}$ time $/ 25$ years $)$ and $\mathrm{Hs}=4.00 \mathrm{~m}$ (1 time/year) or $5.5 \times 10^{-5}$ tides per year.

As the beach level of the gravel beach design is lowered by between 0.5 and $1.00 \mathrm{~m}$ the quantities of overtopping water will only be increased by ca. 10 times. The long term flooding protection efficiency is thus well demonstrated.

5.5.3. Upon completion of all the wave overtopping test series the remaining profile is measured. The test record is given on fig. 8 .

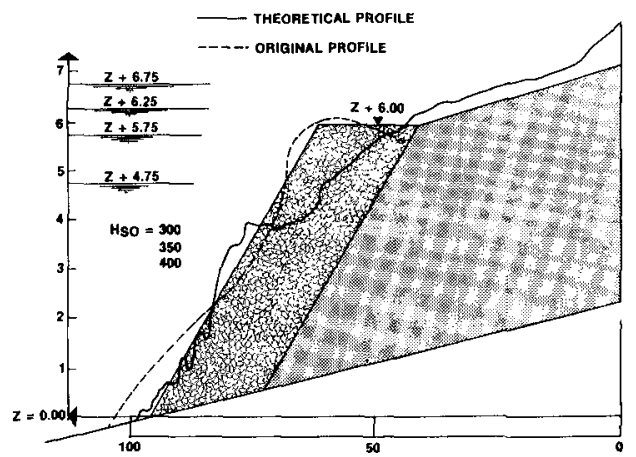

Figure 8. Gravel beach slope after wave overtopping test series ("crach-storm" surges)

The wave overtopping test series can be also used as "crash tests" for the design of wave stability. For the very unlikely event of combined surge waterlevels, wave action and duration, we observe that under no 
circumstances is the sandlayer touched. The beach, at worst, will only be covered by a gravel layer. After such a "crash-storm" the beach needs only be cleaned of the overwashed gravel.

\subsection{Construction phases}

5.6.1. In the wave flume two provisional round heads one at level $\mathrm{Z}+5.00$, the other at level $\mathrm{Z}+3.50$ - have been tested under orthogonal irregular wave action. The test cycles consisted each time of 7 tides with $\mathrm{Hs}=1.00 \mathrm{~m}, 1$ tide with $\mathrm{Hs}=2.00$ and $\mathrm{l}$ tide with $\mathrm{Hs}=3.00 \mathrm{~m}$.

As shown on fig. 9, using a cross section taken $10.00 \mathrm{~m}$ out from the round head, some material will be transported towards the sea-wall mainly from $\mathrm{Hs}=1.00 \mathrm{~m}$, exceedance frequency $\mathrm{ca} .10 \%$ of the tides.

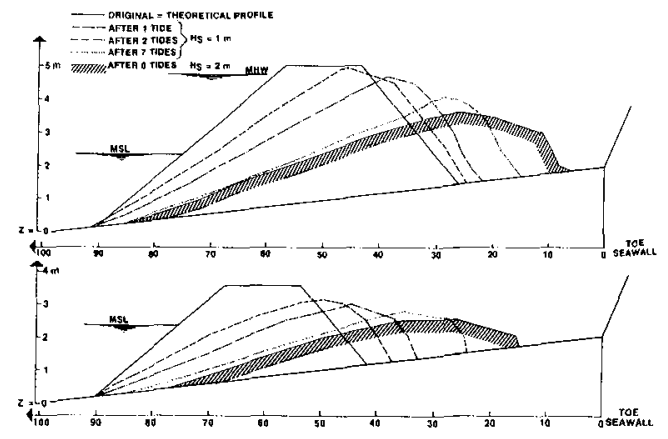

Figure 9. Construction phases - test series

5.6.2. The following guidelines for the construction could be formulated from these tests.

- the gravel beach structure should be constructed (at a maximum) in a calm wave season to avoid waves exceeding $\mathrm{Hs}=1.00 \mathrm{~m}$;

- the gravel mound should be first constructed to a level above HW $(z+4.76)$ in order to decrease the amount of material out of the gravel profile and so as to redress the incurred damages during construction from a dry work level ;

- a gravel mound running section of that nature will probably resist waves of between $\mathrm{Hs}=1.00 \mathrm{~m}$ and $1.50 \mathrm{~m}$. At the round head some damage will occur which can be repaired.

5.6.3. Finalizing the detailed design : taking into account the construction constraints and guidelines several execution methods have been identified and analyzed. The final choice will be that of the succesful contractor in accordance with the job-specifications. 
5.6.4. The detailed design has been finalized as shown on fig. 10 and 11 . The construction phases anticipate the possible gravel losses towards the sandfill section. The project covers ca. $850 \mathrm{~m}$ of beach front. At both ends some minor works had to be conceived to finish the gravel beach. The volumes of material are : sea sand : $300,000 \mathrm{~m}^{3}$ ; sea gravel : $180,000 \mathrm{~m}^{3}$. The works have been estimated at $260 \mathrm{M} \mathrm{BF}$ or some $7,5 \mathrm{M}$ US\$. A construction time of 3 months inclusive down-time is thought feasible.

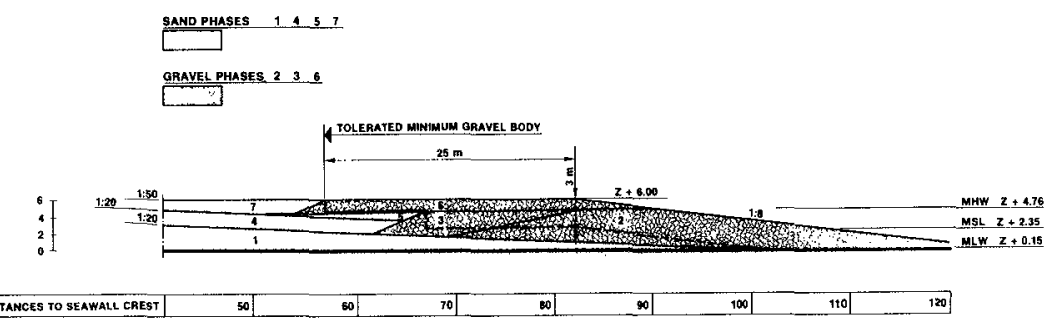

Figure 10. Final design cross section gravel mound and sandfill beach construction phases

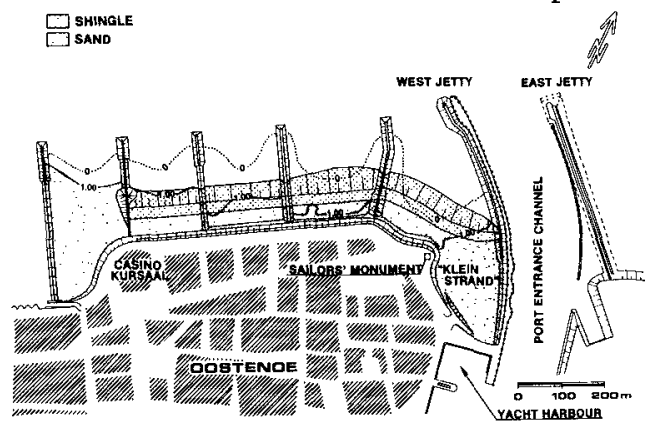

Figure 1l. Final layout beach rehabilitation project depicted on the existing bathymetry, the groyne system and jetties are existing and will remain

\section{Conclusion}

6.1. The gravel beach supported by a sandfill core has been proven to be a feasible and cost effective flood protection alternative, the first objective of the scheme.

6.2. The following secondary goals have also been met:

- new beach recreational facilities in safe conditions for the public ;

- the economic incentive for the much-needed redevelopment of this part of down-town ostend and the beach front;

- the conservation to a large extent of the present seaview from the sea promenade. 


\section{REFERENCES}

- HAECON Gent, various planning and design reports (in dutch).

- Hydraulic Research Station Antwerp : Reports on the physical model testseries of the gravel beach concept (in dutch). 